\title{
Seeing the Inner from Outer
}

\author{
Yoga Yuniadi
}

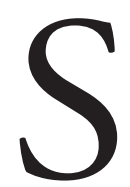

ince Furchgott et $\mathrm{al}^{1}$ showed that acetylcholine requires the presence of endothelial cells to induce vasodilation, the importance of the endothelial cell layer for vascular homeostasis has been increasingly appreciated. Endothelial dysfunction was initially identified as impaired vasodilation to specific stimuli such as acetylcholine or bradykinin. A broader understanding of the term would include not only reduced vasodilation but also a proinflammatory and prothrombic state associated with dysfunction of the endothelium. ${ }^{2}$ Figure 1 describe regulation function of endothelium during normal and dysfunction condition. ${ }^{3}$ In human, endothelial dysfuntion was first described in forearm of hypertensive patient. ${ }^{4}$ Dysfunction of the endothelium has been attributed to the pathophysiology of different forms of cardiovascular disease, including hypertension, coronary artery disease, chronic heart failure, peripheral artery disease, diabetes, and chronic renal failure. ${ }^{2}$

Is endothelial dysfunction a local or systemic condition? The endothelium modulates vasomotion, not only by release of vasodilator substances, but also by an increase in constrictor tone via generation of endothelin and vasoconstrictor prostanoids, as well as via conversion of angiotensin I to angiotensin II at the endothelial surface. These vasoconstrictor agents predominantly act locally, but may also exert some systemic effects and have a role in the regulation of arterial structure and remodeling. ${ }^{5}$

Alamat Korespondensi:

Dr. dr. Yoga Yuniadi, SpJP, Divisi Aritmia, Departemen Kardiologi dan Kedokteran Vaskuler FKUI dan Pusat Jantung Nasional Harapan, Kita, JI S Parman Kav 87 Jakarta I I420, E-mail: yogayun@yahoo.com

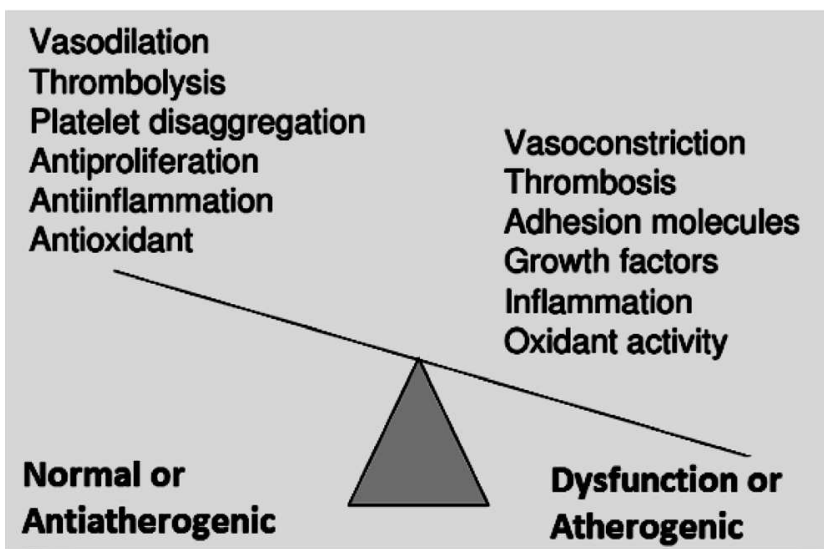

Figure 1. Regulatory functions of the endothelium. Normal or antiatherogenic vs dysfunction or atherogenic propierties. From Esper RJ, et al. ${ }^{3}$

The usual parameter to assess endothelial function is endothelium-dependent vasodilation. Endothelial function may be assessed on forearm resistance arteries by forearm blood flow measurement using strain-gauge plethysmography following acetylcholine or metacholine administration. ${ }^{6}$ Shear stress is the most important stimulation for NO released by the endothelium and leads to a vasodilatation. This vasodilatation is called endothelium-dependent vasodilation. A noninvasive technique that increases shear stress during reactive hyperemia can be utilized to assess endothelial function by measuring flowmediated vasodilation of the brachial artery using ultrasound. ${ }^{7}$

In this edition of the Jurnal Kardiologi Indonesia, Mulia et al using flow mediated dilation (FMD) of brachial artery to predict severity of coronary artery 
disease. The authors hypothetized that the more extensive endothelial dysfunction the more severe coronary artery disease might be developed. They found weak negative correlation between FMD and Gensini score of coronary artery disease severity $(R=$ $-0,227 ; \mathrm{p}$ value $=0,037) .{ }^{8}$ Recent evidences suggests that the endothelial dysfunction is not only the initial stage of the atherosclerotic disease that generates plaque formation, but also can causes plaque growth, and unprotected the high risk plaque leading to develop a vascular event. Choi BJ et al proved that patients with early coronary artery disease and endothelial dysfunction had a higher lipid content in the vascular wall than patients with normal endothelial function. ${ }^{9}$ However, study by Mulia et $\mathrm{al}^{8}$ failed to show concise correlation between the degree of peripheral endothelial dysfunction with severity of atherosclerosis at coronary vessels. The result of the above studies support the hypothesis that endothelial dysfunction is associated with pathogenesis of early atherosclerosis but not with advanced coronary artery disease.

The golden standard evaluation of coronary endothelial function is actually not FMD but coronary resistance vessel responses assessed during cardiac catheterization by Doppler flow measurements. However, if FMD is used the concordance between coronary and brachial endothelial responses is only modest. ${ }^{10}$ Moreover, the magnitude of the FMD depends on the specific protocol used to elicit reactive hyperemia, which differs from center to center at the present time. ${ }^{11}$

Some drugs such as statin, ACE inhibitor, vitamin $\mathrm{C}$, vitamin $\mathrm{E}$ and folic acid have been shown to improve endothelial function. ${ }^{12}$ Those medications together with other risk factors such as diabetes mellitus, smoker and hypertension should be take into account in analysis of endothelial function. It will then need sufficient sample size to get reasonable statistical power. Unfortunatelly, Mulia et al study seems to be under power to analyze the correlation between FMD and coronary artery disease severity if all of above factors are taken into account.

\section{References}

1. Furchgott RF, Zawadzki JV. The obligatory role of endothelial cells in the relaxation of arterial smooth muscle by acetylcholine. Nature 1980;288(5789):373-6.

2. Endemann DH, Schiffrin EL. Endothelial dysfunction. J Am Soc Nephrol 2004;15(8):1983-92.

3. Esper RJ. Interrogando al endotelio. Rev Argent Cardiol 2000;68:429-39.

4. Panza JA, Quyyumi AA, Brush JE, Jr., Epstein SE. Abnormal endothelium-dependent vascular relaxation in patients with essential hypertension. N Engl J Med 1990;323(1):22-7.

5. Deanfield JE, Halcox JP, Rabelink TJ. Endothelial function and dysfunction: testing and clinical relevance. Circulation 2007;115(10):1285-95.

6. Perticone F, Ceravolo R, Pujia A, Ventura G, Iacopino S, Scozzafava A, et al. Prognostic significance of endothelial dysfunction in hypertensive patients. Circulation 2001;104(2):191-6.

7. Celermajer DS, Sorensen KE, Gooch VM, Spiegelhalter DJ, Miller OI, Sullivan ID, et al. Non-invasive detection of endothelial dysfunction in children and adults at risk of atherosclerosis. Lancet 1992;340(8828):1111-5.

8. Mulia E, Sunu I, Joesoef AH, Harimurti GN. Correlation of brachial flow mediated dilation with severity of coronary artery disease. J Kardiol Indones 2013;34(2):71-9.

9. Choi BJ, Prasad A, Gulati R, Best PJ, Lennon RJ, Barsness GW, et al. Coronary endothelial dysfunction in patients with early coronary artery disease is associated with the increase in intravascular lipid core plaque. Eur Heart J 2013;34(27):2047-54.

10. Anderson TJ, Uehata A, Gerhard MD, Meredith IT, Knab S, Delagrange D, et al. Close relation of endothelial function in the human coronary and peripheral circulations. J Am Coll Cardiol 1995;26(5):1235-41.

11. Corretti MC, Anderson TJ, Benjamin EJ, Celermajer D, Charbonneau F, Creager MA, et al. Guidelines for the ultrasound assessment of endothelial-dependent flow-mediated vasodilation of the brachial artery: a report of the International Brachial Artery Reactivity Task Force. J Am Coll Cardiol 2002;39(2):257-65.

12. Flammer AJ, Anderson T, Celermajer DS, Creager MA, Deanfield J, Ganz P, et al. The assessment of endothelial function: from research into clinical practice. Circulation 2012;126(6):753-67. 